\title{
APPLICATION OF BRYOPHYTE RHIZOID-ASSOCIATED BACTERIA INCREASES SILICON ACCUMULATION AND GROWTH IN MAIZE (ZEA MAYS L.) SEEDLINGS
}

\author{
HU, L. ${ }^{1,2}-$ XU, C. C. ${ }^{3}-$ WANG, J. ${ }^{1}-$ CHEN, D. Q. ${ }^{1}-$ ZENG, R. S. ${ }^{1}-$ Song, Y. Y. ${ }^{1}-$ CHEN, D. M. ${ }^{*}$ \\ ${ }^{1}$ Key Laboratory of Ministry of Education for Genetics, Breeding and Multiple Utilization of \\ Crops, College of Crop Science, Fujian Agriculture and Forestry University, Fuzhou, China \\ ${ }^{2}$ Key Laboratory of Beibu Gulf Environment Change and Resources Utilization of Ministry of \\ Education, Nanning Normal University, Nanning, China \\ ${ }^{3}$ College of Life Sciences, Fujian Agriculture and Forestry University, Fuzhou, China \\ *Corresponding author \\ e-mail: dongmeifj@163.com; phone: +86-130-1572-5866; fax: +86-591-8378-9483 \\ (Received $19^{\text {th }}$ Jun 2019; accepted $2^{\text {nd }}$ Sep 2019)
}

\begin{abstract}
Silicon (Si) enhances plant resistance to various forms of stress. However, the availability of Si as a plant nutrient is frequently limited. Bryophytes are able to grow on the surface of rocks and buildings with high $\mathrm{Si}$ accumulation. Therefore, bryophyte rhizoids might harbor microorganisms capable of solubilizing Si. In this study, silicate solubilizing bacteria (SSB) were isolated from the rhizoids of the bryophyte Hypnum plumaeforme L. to examine their effects on Si weathering and growth of maize (Zea mays L.). Molecular phylogeny and 16S rRNA gene sequence analysis demonstrated that the dominant bacterial strain B1-5 was a member of the Kosakonia genus. The concentrations of soluble Si released from the feldspar and quartz powder in liquid media with strain B1-5 inoculation were higher than those of the control. B1-5 inoculation in pot soil significantly increased the water-extractable Si content in soil, improved Si uptake and accumulation in maize plants, and promoted seedling growth. These results not only prove the existence of SSB in bryophyte rhizoids, but also demonstrate a new approach to searching for effective biological Si fertilizers.
\end{abstract}

Keywords: silicate solubilizing bacteria, microbial weathering, molecular phylogeny, Kosakonia, biological fertilizer

\section{Introduction}

Silicon ( $\mathrm{Si}$ ) is the second most abundant element after oxygen in soil. It occurs mostly in the form of dioxide and silicates (Myshlyaeva and Krasnoshchekov, 1974), which cannot be directly used by plants. Only water-soluble monosilicic acid $\left[\mathrm{Si}(\mathrm{OH})_{4}\right]$, a product of the weathering of rocks and soil minerals, is available to plants (Epstein, 1994; Raven, 1983). Si has not yet been recognized as an essential nutrient element for plants, but its beneficial effects on resistance have been extensively reported in numerous crops (Epstein, 1999). In $2015 \mathrm{Si}$ was listed as a "beneficial substance" by the International Plant Nutrition Institute, USA (Reynolds et al., 2016). Increasing evidences indicate that $\mathrm{Si}$ can alleviate both biotic and abiotic stresses including pathogens, herbivores, extreme temperature, water deficiency, high salinity and nutrient stresses (Debona et al., 2017; Ma, 2004; Wu et al., 2017). Nitrogen (N), phosphorus (P) and potassium $(\mathrm{K})$ fertilizers are widely applied in agricultural production, but $\mathrm{Si}$ fertilizer is usually neglected. Si deficiency frequently occurs as a result of Si removal by continuous crop harvest (Liang et al., 2015). Thus, it is of significance to effectively convert unavailable $\mathrm{Si}$ in the soils into a form plants can utilize. 
Soil microbes play a crucial role in nutrient availability and mineral weathering from primary minerals (Vessey, 2003). Most related studies focused on the $\mathrm{P}$ and $\mathrm{K}$ solubilizing abilities of some microorganisms as seen in Table 1.

Table 1. Studies of phosphate and potassium solubilizing bacteria in crops

\begin{tabular}{c|c|c}
\hline Crop name & Solubilizing capacity & Citation \\
\hline Barely (Hordeum vulgare L.) & $\mathrm{P}$ & Mehrvarz and Chaichi, 2008 \\
Wheat (Triticum aestivum L.) & $\mathrm{P}$ & Afzal et al., 2005 \\
Wheat (Triticum aestivum L.) & $\mathrm{K}$ & Sheng and He, 2006 \\
Pepper (Capsicum annuum L.) & P and K & Han and Lee, 2006 \\
Cucumber (Cucumis sativus L.) & P and K & Han and Lee, 2006 \\
Tobacco (Nicotiana tabacum L.) & $\mathrm{K}$ & Zhang and Kong, 2014 \\
Cotton (Gossypium barbadense L.) & $\mathrm{K}$ & Sheng, 2005 \\
Rape (Brassica campestris L.) & $\mathrm{K}$ & Sheng, 2005 \\
Peanut (Arachis hypogaea L.) & $\mathrm{K}$ & Youssef et al., 2010 \\
Sesame (Sesamum indicum L.) & $\mathrm{K}$ & Youssef et al., 2010 \\
Ryegrass (Lolium rigidum L.) & $\mathrm{K}$ & Xiao et al., 2017 \\
Maize (Zea mays L.) & $\mathrm{K}$ & Singh et al., 2010 \\
\hline
\end{tabular}

The role of silicate solubilizing bacteria (SSB), which can solubilize silicon from silicate bearing mineral and rocks (Bosecker, 1997), is largely ignored. Use of highlyefficient SSB is a promising approach for enhancing crop yield and defense in $\mathrm{Si}$ deficient soil.

An analysis of the Si contents in 175 plant species collected from a botanical garden shows that Bryophyta (3.46\%) contains the highest $\mathrm{Si}$, following by Pteridophyta (1.4\%), Gymnospermae (0.5\%), Angiospermae (0.13\%) (Takahashi and Miyake, 1976a, b, c), suggesting that bryophytes are Si accumulators with high Si content. Therefore, we speculated that bryophyte rhizoids harbor certain SSB capable of solubilizing Si from poor nutrient habitats.

In the present study, our aims were to: (1) isolate and characterize bryophyte rhizoids-associated silicate bacteria, (2) determine the Si-solubilizing ability of selected bacteria, and (3) examine the effect of soil inoculation with selected bacteria on $\mathrm{Si}$ availability in the soil, Si uptake and plant growth in maize.

\section{Materials and methods}

\section{Plants, soil and mineral}

Bryophyte Hypnum plumaeforme was collected from rock walls in the back hill on Jinshan Campus of Fujian Agriculture and Forestry University, Fuzhou, China (119 $54^{\prime}$ E, $26^{\circ} 05^{\prime} \mathrm{N}$ ) in July, 2018. Bryophytes from eight random sampling locations were kept in sterilized plastic Petri-dishes until the isolation experiment began in the same day.

The soils for maize potting were collected from a hillside near the university campus. The soil was a red soil (Typic Hapludults) (Soil Survey Staff, 2010). The properties of the soil were: $\mathrm{pH}\left(1: 2.5 \mathrm{w} / \mathrm{v}\right.$ water) 5.5 ; organic $\mathrm{C} 10.03 \mathrm{~g} \cdot \mathrm{kg}^{-1}$; total $\mathrm{N} 1.28 \mathrm{~g} \cdot \mathrm{kg}^{-1}$; available $\mathrm{N} 19.3 \mathrm{mg} \cdot \mathrm{kg}^{-1}$; total $\mathrm{P} 0.13 \mathrm{~g} \cdot \mathrm{kg}^{-1}$; available $\mathrm{P} 12.6 \mathrm{mg} \cdot \mathrm{kg}^{-1}$; total $\mathrm{K}$ $2.05 \mathrm{~g} \cdot \mathrm{kg}^{-1}$; available $\mathrm{K} 154.6 \mathrm{mg} \cdot \mathrm{kg}^{-1}$, water-extractable Si $34.3 \mathrm{mg} \cdot \mathrm{kg}^{-1}$. Seeds of 
maize (Zea mays, cultivar Yuecai) were obtained from the Crop Research Institute, Guangdong Academy of Agricultural Sciences, Guangzhou, China.

Mineral powders, feldspar $\left(\mathrm{KAlSi}_{3} \mathrm{O}_{8}, \mathrm{SiO}_{2} 68.09 \%\right)$ and quartz $\left(\mathrm{SiO}_{2} 98.81 \%\right)$, were manufactured by Foshan Hongda Ceramics Co., Ltd and passed through $0.075 \mathrm{~mm}$ mesh sieve. The powders were rinsed three times in pure water to eliminate soluble $\mathrm{Si}$.

\section{Isolation of silicate bacteria from bryophyte rhizoids}

All collected bryophytes were slightly shaken to remove sands loosely adhering to the rhizoids. The rhizoids with the remaining adherd soil were swayed in $25 \mathrm{~mL}$ sterile water with tweezers, and the water was transferred to a $50 \mathrm{~mL}$ plastic tubes. The tubes were shaken with a vortex mixer for $15 \mathrm{~s}$. The mixture was kept at room temperature for $30 \mathrm{~min}$. The serially diluted suspension was plated on the surface of Aleksandrov's medium for silicate bacterial culture containing $0.5 \%$ sucrose, $0.05 \% \mathrm{MgSO}_{4} \cdot 7 \mathrm{H}_{2} \mathrm{O}$, $0.5 \% \mathrm{FeCl}_{3}, 0.2 \% \mathrm{Na}_{2} \mathrm{HPO}_{4}, 0.01 \% \mathrm{CaCO}_{3}, 0.1 \% \mathrm{KAlSi}_{3} \mathrm{O}_{8}$, and $2 \%$ Agar, $\mathrm{pH} 7.2(\mathrm{Hu}$ et al., 2018). The Petri-dishes were placed in an incubator at $28{ }^{\circ} \mathrm{C}$ for $5 \mathrm{~d}$. The growth of bacteria was checked every day. Fast-growing isolates with different morphology were further purified. The pure colonies were inoculated into liquid medium and preserved in $25 \%$ glycerol solution at $-80{ }^{\circ} \mathrm{C}$ for future use.

\section{Mineral dissolution experiment}

The dominant strain was selected to test the ability to solubilize the mineral. The liquid medium consisted of $1 \%$ sucrose, $0.05 \%$ yeast extract, $0.1 \% \mathrm{NH}_{4} \mathrm{SO}_{4}, 0.2 \%$ $\mathrm{Na}_{2} \mathrm{HPO}_{4}, 0.05 \% \mathrm{MgSO}_{4} \cdot 7 \mathrm{H}_{2} \mathrm{O}, 0.01 \% \mathrm{NaCl}, 0.01 \% \mathrm{CaCO}_{3}, 5 \mathrm{~g}$ mineral powder, $\mathrm{pH}$ 7.2. Each conical flask $(250 \mathrm{~mL})$ contained $100 \mathrm{~mL}$ autoclaved liquid medium and $5 \mathrm{~mL}$ bacterial inocula $\left(10^{6} \mathrm{cfu} \mathrm{mL}^{-1}\right)$ as inoculation treatment. Five $\mathrm{mL}$ of sterilized inoculum were also added to the liquid medium to serve as control.

Feldspar and quartz were used as $\mathrm{Si}$ mineral respectively in two separate experiments. The inoculation and corresponding control were replicated three times. Each flask was maintained at $180 \mathrm{rpm}$ for $7 \mathrm{~d}$ at $28{ }^{\circ} \mathrm{C}$. The fermented broth was centrifuged at $8000 \mathrm{~g}$ for $20 \mathrm{~min}$. The solubilized Si concentration in the supernatant was determined using the colorimetric molybdenum blue method described by Pettersson and Karlberg (1999).

\section{Molecular identification}

Genomic DNA was extracted using the DNA extraction Kit (Qiagen, USA) according to the manufacture's protocol. The universal primers for 16S rRNA sequence amplification were 27F (5'-GTTTGATCCTGGCTCAG-3') and 1492R (5'GGTTACCTTGTTACGACTT-3') (Lin et al., 2012). The PCR reaction system had a volume of $25 \mu \mathrm{l}$, including Taq PCR Master Mix $12.5 \mu \mathrm{l}$, primer $2 \mu \mathrm{l}, \mathrm{ddH}_{2} \mathrm{O} 9.5 \mu \mathrm{l}$, and DNA template $1 \mu \mathrm{l}$. The PCR was performed as follows: hot start at $94{ }^{\circ} \mathrm{C}$ for $5 \mathrm{~min}$, followed by 30 cycles of denaturation at $94{ }^{\circ} \mathrm{C}$ for $30 \mathrm{~s}$, annealing at $55^{\circ} \mathrm{C}$ for $30 \mathrm{~s}$, and extension at $72{ }^{\circ} \mathrm{C}$ for $60 \mathrm{~s}$. A final extension step lasted $8 \mathrm{~min}$ at $72{ }^{\circ} \mathrm{C}$. The PCR products were purified and sequenced by Shanghai Biosune Biological Technology Co., Ltd. The sequencing results were analyzed using NCBI database to find the closely related homologous sequences.

The sequence and the reference sequences with the highest similarities were aligned using Clustalx 1.83 and phylogenetic analyses was done using MEGA version 4 with 
the neighbor-joining method, p-distance and 1000 bootstrap replicates (Tamura et al., 2007; Thompson et al., 1997).

\section{Pot experiment}

Maize seeds were surface-sterilized with $10 \% \mathrm{H}_{2} \mathrm{O}_{2}$ for $10 \mathrm{~min}$, and then rinsed 5 times with distilled water. The seeds were soaked in distilled water for $24 \mathrm{~h}$, and then pre-germinated for $48 \mathrm{~h}$ at $28{ }^{\circ} \mathrm{C}$. One seedling was transplanted to a $1 \mathrm{~L}$ plastic pot with $750 \mathrm{~g}$ dry sterilized soil. The soil were autoclaved thrice in three consecutive days. Meanwhile, the cells in cultured bacterial broth were collected by centrifugation at $8000 \mathrm{~g}$ for $20 \mathrm{~min}$ at $4{ }^{\circ} \mathrm{C}$ and washed with sterilized tap water. The pelleted cells were resuspended with sterilized water and then the cells were adjusted to around $10^{6} \mathrm{cfu} \mathrm{mL}^{-1}$ as determined by a standard growth curve based on optical density reading at $600 \mathrm{~nm}$ using a spectrophotometer (Ling et al., 2009). The experiment was established with two groups: one group was inoculated with $10 \mathrm{~mL}$ bacterial suspension as inoculation treatment, and the other group was added with $10 \mathrm{~mL}$ distilled water as control. A total of 20 pots with maize plants were divided into two groups. After $7 \mathrm{~d}$, all plants were fertilized with $50 \mathrm{~mL}$ Hoagland nutrient solution (Hoagland and Arnon, 1950).

All plants were harvested 5 weeks after transplanting. The roots were washed and cleaned, and stem diameters were measured. All plants samples were dried at $70{ }^{\circ} \mathrm{C}$ for $3 \mathrm{~d}$, then weighed. The Si contents of dry samples were then analyzed by molybdenum blue colorimetric method described by Dannon and Wydra (2004). The waterextractable $\mathrm{Si}$ content of air-dry soil samples (1:10 w/v water) was determined by colorimetric molybdenum blue method described by Wang et al. (2004).

\section{Statistical analysis}

$\mathrm{Si}$ concentrations in culture solution, growth indexes and $\mathrm{Si}$ content of plants and soils were analyzed using t-test $(\mathrm{P}<0.05)$ to determine difference between bacterial inoculation and control. All analyses were performed with the SPSS 13.0 software package (SPSS Inc.).

\section{Results and discussion}

\section{Isolation silicate bacteria from the bryophyte rhizoids}

Si-solubilizing bacterial isolates were obtained from the bryophyte Hypnum plumaeforme rhizoids on rock walls (Fig. 1A), and one of them showed the dominant colony which was named as B1-5, and kept for further study. On the Aleksandrov plates, the strain B1-5 formed round, smooth, convex, slimy, elastic, translucent and colorless colonies (Fig. 1B). Silicate solubilizing bacteria (SSB) can solubilize silicon from silicate mineral (Bosecker, 1997). Bryophyte with high Si-accumulation mostly can grow on the surface of rocks and buildings. So it raises the possibility that some SSB may adhere to the bryophyte rhizoids.

\section{Molecular identification based on $16 S$ rRNA analysis}

About 1500 bp band was obtained from the amplification of 16S rRNA gene sequence from the strain B1-5. The 16S rRNA gene sequence of B1-5 clones was submitted to GenBank with accession number MH051262. Phylogenetic analysis 
showed that B1-5 and all 6 Kosakonia species formed a branch, and that other outgroup species formed different branches (Fig. 2). Thus, the B1-5 strain belongs to the Kosakonia genus. Figure 2 also showed that strain B1-5 shared the highest sequence similarities with Kosakonia cowanii. Thus, strain B1-5 was identified as a member of Kosakonia.

Several Kosakonia species isolated from soils and trees promote plant growth (Brady et al., 2013). Diazotrophic bacteria, K. pneumoniae and $K$. radicincitans were found to be associated sugarcane at Northeast Region of Brazil (Antonio et al., 2016). $K$. radicincitans improves fruit yield and quality of Solanum lycopersicum (Berger et al., 2017). K. radicincitans alters Arabidopsis thaliana root and root exudate metabolism (Witzel et al., 2017). K. pseudosacchari sp. nov., an endophyte of Zea mays was isolated (Kaempfer et al., 2016).

\section{Si solubilizing activity of the bacteria}

The ability of strain B1-5 to solubilize Si was assessed in liquid media containing mineral powders of $\mathrm{KAlSi}_{3} \mathrm{O}_{8}$ and $\mathrm{SiO}_{2}$ (Fig. 3). After 7 days of incubation, a significant increase in soluble $\mathrm{Si}$ concentration of the medium with $\mathrm{KAlSi}_{3} \mathrm{O}_{8}(\mathrm{t}=$ 5.344, $\mathrm{df}=4, \mathrm{P}=0.006)$ or $\mathrm{SiO}_{2}(\mathrm{t}=-43.466$, $\mathrm{df}=4, \mathrm{P}<0.001)$ supplement was observed in inoculated versus control seedlings.

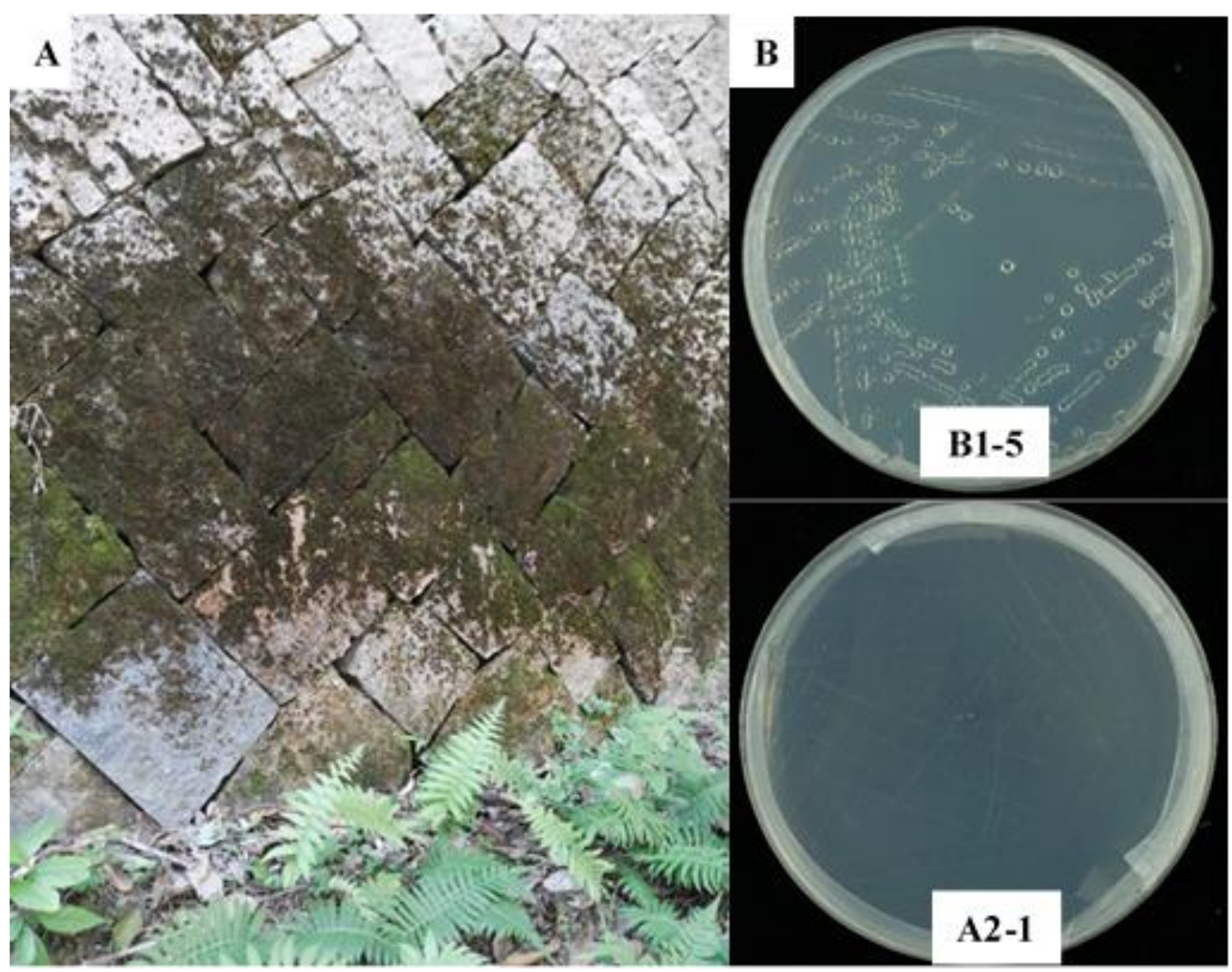

Figure 1. Habitat of bryophyte Hypnum plumaeforme on rock walls (A). Characteristics of strains B1-5 and A2-1 colonies after grown on Aleksandrov medium for $48 \mathrm{~h}(\mathrm{~B})$ 


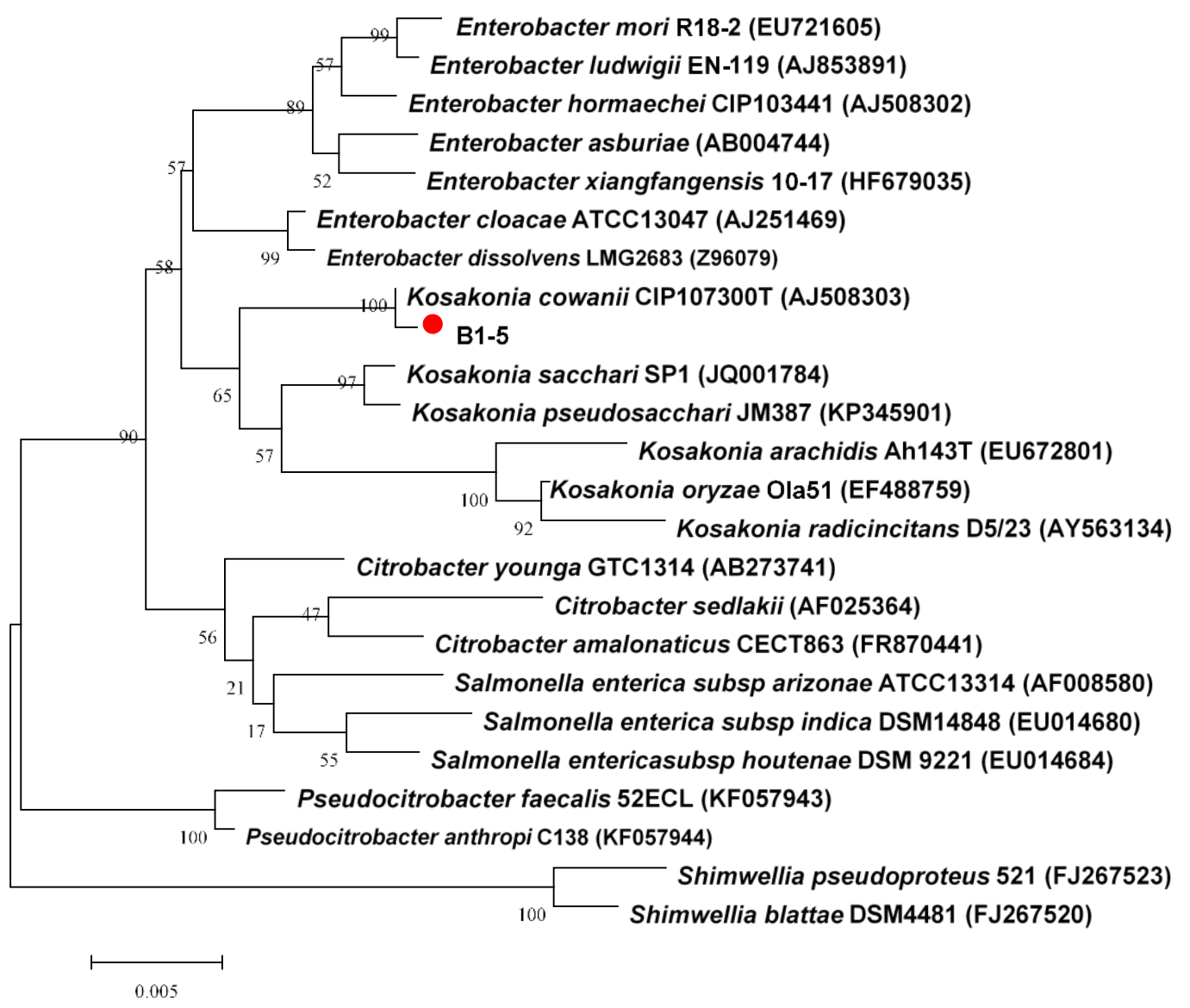

Figure 2. Phylogenetic dendrogram based on comparative analysis of the 16S rRNA gene sequence, showing the relationship among strain B1-5 and other related species and genera. The GenBank sequence accession numbers were indicated in brackets after the strain names. The dendrogram was generated using the neighbour-joining method in the bootstrap test (1000 replicates)

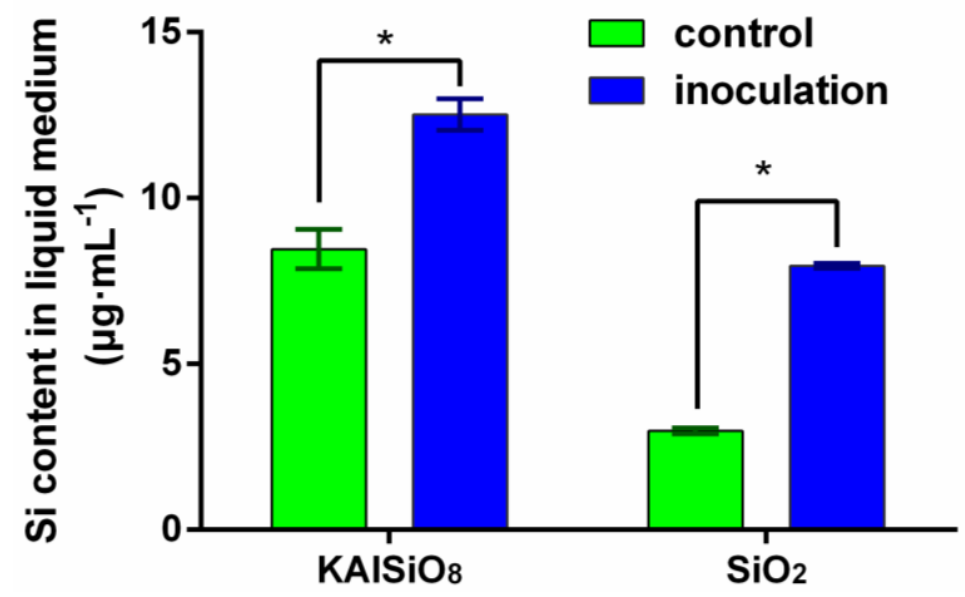

Figure 3. Si content in $\mathrm{KAlSi}_{3} \mathrm{O}_{8}-(\mathrm{A})$ and $\mathrm{SiO} 2$-containing (B) liquid medium with and without inoculation with the isolated silicate bacterium strain B1-5. Si content was determined $7 d$ after inoculation with strain B1-5. Significant differences $(P<0.05)$ between inoculation and noninoculated control are indicated by asterisk above bars. Values are mean \pm standard error from three replicates 
Here we found the B1-5 bacterial strain was able to solubilize silicate from Sibearing mineral in fermentation liquid. Indeed, microbial leaching is a simple and effective technology for metal extraction from low-grade ores and mineral concentrates, and this method is being increasingly applied in mining industry (Bosecker, 1997). Mineral weathering mechanism has been increasingly clarified in terms of chemical weathering processes. These microbes have been indicated to accelerate the dissolution of silicates by perturbing mineral-water equilibria and reaction dynamics, the production of chelating agents, proton, organic ligands, hydroxyl anion, extracellular polysaccharides and enzymes, and silicate precipitation by metal sorption at the cell membrane (Bennett et al., 2001). However, the influence of bacteria in this process and its molecular mechanisms are still unclear (Uroz et al., 2009).

\section{Effect of strain B1-5 on maize growth and Si content in soil and plants}

Maize seedlings grown in soils inoculated with B1-5 showed greater shoot diameter $(\mathrm{t}=-4.745, \mathrm{df}=18, \mathrm{P}<0.001)$ and dry biomass $(\mathrm{t}=-2.634, \mathrm{df}=18, \mathrm{P}=0.017)$ than un-inoculated plants (Fig. 4). Soil inoculation with B1-5 strain significantly increased the growth of maize plants.
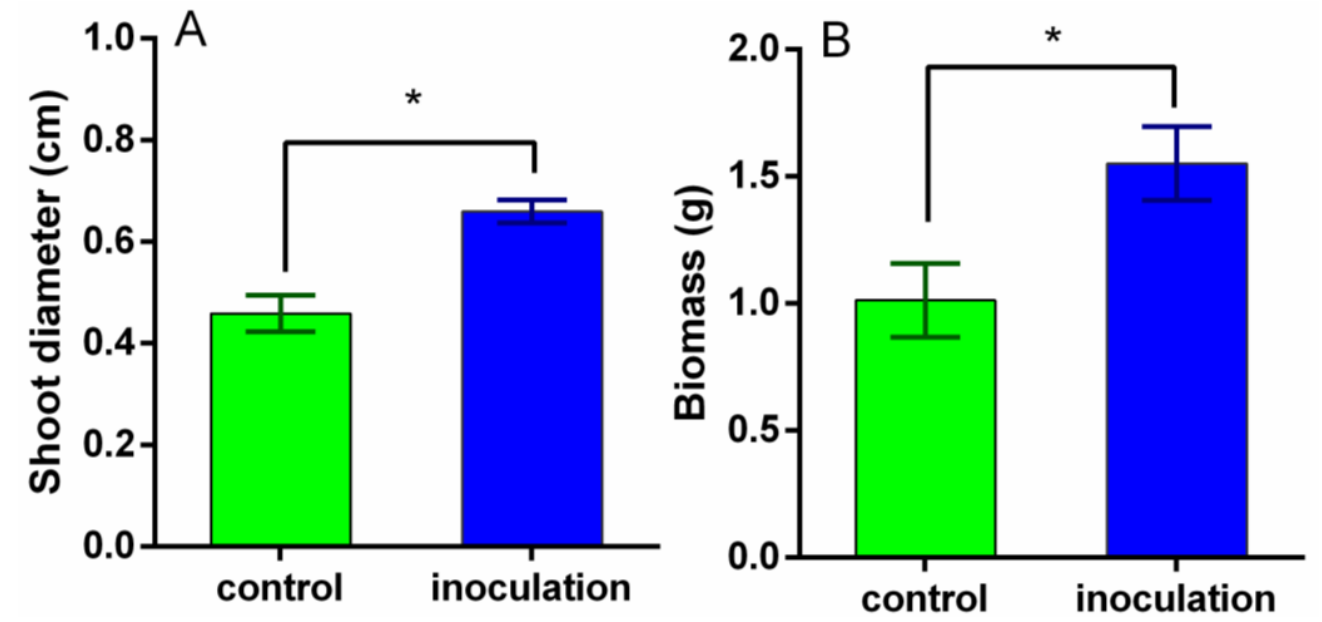

Figure 4. Shoot diameter $(A)$ and biomass $(B)$ of maze seedlings grown in the soil with and without inoculation of strain B1-5. Significant differences $(P<0.05)$ between inoculation and non-inoculated control are indicated by asterisk above bars. Values are mean \pm standard error from ten replicates

The soluble Si content in the soil inoculated with B1-5 strain was higher than that in un-inoculated control $(\mathrm{t}=-3.67, \mathrm{df}=18, \mathrm{P}=0.001)$ (Fig. 5A). Maize plants grown in inoculated soil showed significantly higher $\mathrm{Si}$ level in shoots $(\mathrm{t}=-2.55$, $\mathrm{df}=18$, $\mathrm{P}=0.020)$ and roots $(\mathrm{t}=-2.228, \mathrm{df}=18, \mathrm{P}=0.039)$ than those in un-inoculated plants (Fig. 5B). Inoculation with B1-5 strain significantly increased soluble Si release from the soil and Si uptake by maize plants.

Our study clearly illustrated that the growth and Si content of maize plants were improved by inoculation with B1-5 strain via enhancement of soil Si availability and plant $\mathrm{Si}$ uptake. This is consistent with the findings that SSB, Bacillus circulans Burkholderia eburnean and Enterobacter ludwigii, increased the release of $\mathrm{Si}$ in soil and $\mathrm{Si}$ acquisition by plants (Kang et al., 2017; Lee et al., 2019; Zahra et al., 1984). Many studies have 
showed that $\mathrm{Si}$ application improves the growth of monocot crops including rice, sugarcane (Saccharum officinarum) and turf (Lolium perenne) (Nanayakkara et al., 2008; Savant et al., 1999; Snyder, 2001). Moreover, two field experiments in India have also reported that silicon solubilizing bacteria improve silicon uptake and crop yield in rice and sugarcane (Brindavathy et al., 2012; Pedda et al., 2016).

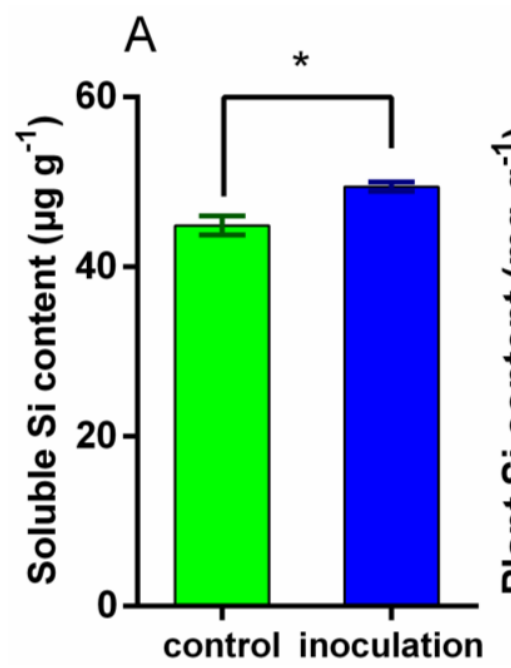

B $\square$ control

inoculation

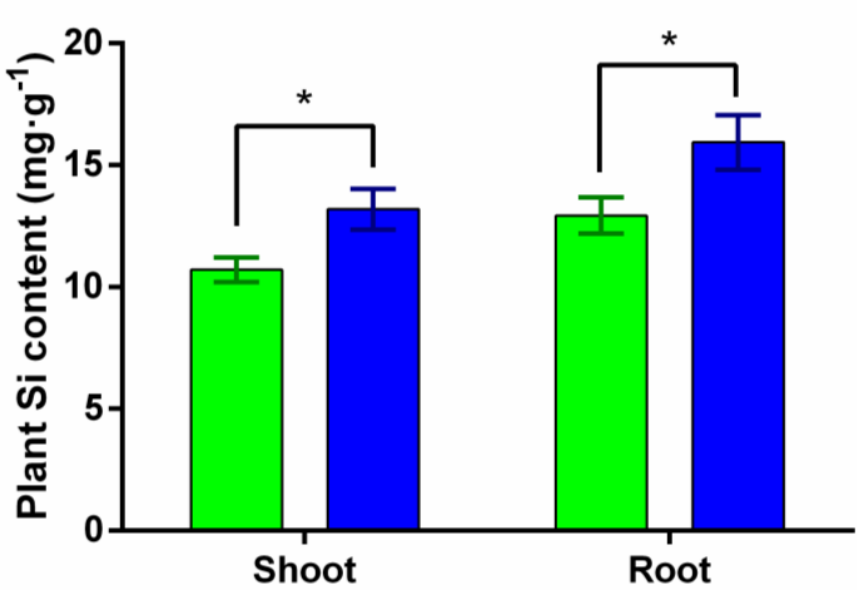

Figure 5. (A) Soluble Si content in strain B1-5-inoculated and un-inoculated soils. (B) Si content in the shoots (left) and roots (right) of maize seedlings grown in strain B1-5-inoculated and un-inoculated soils. Significant differences $(P<0.05)$ between inoculation and control are indicated by asterisk by different letters above bars. Values are mean \pm standard error from ten replicates

\section{Conclusion}

In conclusion, this study not only highlights the existence of bryophyte rhizoidsassociated silicate solubilizing bacteria, but also opens up a new approach searching for Si-solubilizing bacteria to increase $\mathrm{Si}$ availability in soil. Use of silicate solubilizing bacteria biofertilizer may serve as an important approach to increase Si availability and crop production. More detailed mechanisms of microbiological molecular biology and metabonomics about mineral weathering await further research.

Acknowledgements. This work was supported by the National Natural Science Foundation of China (31670414, 31770474), Fujian Provincial Excellent Youth Science Foundation (2017J06010), and FujianTaiwan Joint Innovative Center for Germplasm Resources and Cultivation of Crop (FJ 2011 Program, NO.2015-75).

\section{REFERENCES}

[1] Afzal, A., Ashraf, M., Asad, S. A., Farooq, M. (2005): Effect of phosphate solubilizing microorganisms on phosphorus uptake, yield and yield traits of wheat (Triticum aestivum L.) in rainfed area. - Int J Agric Biol 7: 207-209.

[2] Antonio, C. D. S., Rouws, L. F. M., Teixeira, K. R. S., Reis, V. M. (2016): Diazotrophic bacteria associated to sugarcane varieties cropped at northeast region of Brazil. - Revista Brasileirade Ciencias Agrarias 11: 272-280. 
[3] Bennett, P. C., Rogers, J. R., Choi, W. J., Hiebert, F. K. (2001): Silicates, silicate weathering, and microbial ecology. - Geomicrobiol J 18: 3-19.

[4] Berger, B., Baldermann, S., Ruppel, S. (2017): The plant growth-promoting bacterium Kosakonia radicincitans improves fruit yield and quality of Solanum lycopersicum. - J Sci Food Agric 97: 4865-4871.

[5] Bosecker, K. (1997): Bioleaching: metal solubilization by microorganisms. - FEMS Microbiol Rev 20: 591-604.

[6] Brady, C., Cleenwerck, I., Venter, S., Coutinho, T., De Vos, P. (2013): Taxonomic evaluation of the genus Enterobacter based on multilocus sequence analysis (MLSA). Syst Appl Microbiol 36: 309-319.

[7] Brindavathy, R., Dhara, N., Rajasundari, K. (2012): Biodissolution of Silica by Silicon Bacteria in Sugarcane Rhizosphere. - Res J Agri Sci 3: 1042-1044.

[8] Dannon, E. A., Wydra, K. (2004): Interaction between silicon amendment, bacterial wilt development and phenotype of Ralstonia solanacearum in tomato genotypes. - Physiol Mol Plant Pathol 64: 233-243.

[9] Debona, D., Rodrigues, F. A., Datnoff, L. E. (2017): Silicon's role in abiotic and biotic plant stresses. - Annu Rev Phytopathol 55: 85-107.

[10] Epstein, E. (1994): The anomaly of silicon in plant biology. - P Natl Acad Sci USA 91: 11-17.

[11] Epstein, E. (1999): Silicon. - Annu Rev Plant Biol 50: 641-664.

[12] Han, H. S., Lee, K. D. (2006): Effect of co-inoculation with phosphate and potassium solubilizing bacteria on mineral uptake and growth of pepper and cucumber. - Plant Soil Environ 52: 130-136.

[13] Hoagland, D. R., Arnon, D. I. (1950): The water-culture method for growing plants without soil. - Calif Agric Exp Stn Circ 347: 357-359.

[14] Hu, L., Xia, M., Lin, X., Xu, C., Zeng, R., Song, Y. (2018): Earthworm gut bacteria increase silicon bioavailability and acquisition by maize. - Soil Biol Biochem 125: 215221.

[15] Kaempfer, P., McInroy, J. A., Doijad, S., Chakraborty, T., Glaeser, S. P. (2016): Kosakonia pseudosacchari sp nov., an endophyte of Zea mays. - Syst Appl Microbiol 39: 1-7.

[16] Kang, S. M., Waqas, M., Shahzad, R., You, Y. H., Asaf, S., Khan, M. A., Lee, K. E., Joo, G. J., Kim, S. J., Lee, I. J. (2017): Isolation and characterization of a novel silicatesolubilizing bacterial strain Burkholderia eburnea CS4-2 that promotes growth of japonica rice (Oryza sativa L. cv. Dongjin). - Soil Sci Plant Nutr 63: 233-241.

[17] Lee, K. E., Adhikari, A., Kang, S. M., You, Y. H., Joo, G. J., Kim, J. H., Kim, S. J., Lee, I. J. (2019): Isolation and characterization of the high silicate and phosphate solubilizing novel strain Enterobacter ludwigii GAK2 that promotes growth in rice plants. Agronomy 9: 144.

[18] Liang, Y., Nikolic, M., Belanger, R., Haijun, G., Song, A. (2015): Silicon in Agriculture. From Theory to Practice. - Springer, Dordrecht.

[19] Lin, W., Wang, Y., Li, B., Pan, Y. (2012): A biogeographic distribution of magnetotactic bacteria influenced by salinity. - ISME J 6: 475-479.

[20] Ling, T. Y., Jong, H. J., Apun, K., Sulaiman, W. H. W. (2009): Quantifying Escherichia coli release from soil under high-intensity rainfall. - T ASABE 52: 785-792.

[21] Ma, J. F. (2004): Role of silicon in enhancing the resistance of plants to biotic and abiotic stresses. - J Plant Nutr Soil Sci 50: 11-18.

[22] Mehrvarz, S., Chaichi, M. R. (2008): Effect of phosphate solubilizing microorganisms and phosphorus chemical fertilizer on forage and grain quality of barely (Hordeum vulgare L.). - Agri Environ Sci 3: 822-828.

[23] Myshlyaeva, L. V., Krasnoshchekov, V. V. (1974): Analytical Chemistry of Silicon. Wiley, New York. 
[24] Nanayakkara, U. N., Uddin, W., Datnoff, L. E. (2008): Application of silicon sources increases silicon accumulation in perennial ryegrass turf on two soil types. - Plant Soil 303: 83-94.

[25] Pedda, K. S., Mohiuddin, G., Balasubramaniam, P., Mahendran, P. P. (2016): Performance of silicate solubilizing bacteria on silicon uptake and yield of rice under lowland ecosystem. - J Appl Nat Sci 8: 55-59.

[26] Pettersson, Å. K., Karlberg, B. (1999): Simultaneous determination of orthophosphate and silicate in brackish water. - Anal Chim Acta 378: 183-189.

[27] Raven, J. A. (1983): The transport and function of silicon in plants. - Biological Reviews 58: $179-207$.

[28] Reynolds, O. L., Padula, M. P., Zeng, R., Gurr, G. M. (2016): Silicon: potential to promote direct and indirect effects on plant defense against arthropod pests in agriculture. - Front Plant Sci 7. DOI: 10.3389/fpls.2016.00744.

[29] Savant, N., Korndörfer, G., Datnoff, L., Snyder, G. (1999): Silicon nutrition and sugarcane production: a review. - J Plant Nutr 22: 1853-1903.

[30] Sheng, X. F. (2005): Growth promotion and increased potassium uptake of cotton and rape by a potassium releasing strain of Bacillus edaphicus. - Soil Biol Biochem 37: 19181922.

[31] Sheng, X. F., He, L. Y. (2006): Solubilization of potassium-bearing minerals by a wildtype strain of Bacillus edaphicus and its mutants and increased potassium uptake by wheat. - Can J Microbiol 52: 66-72.

[32] Singh, G., Biswas, D. R., Marwaha, T. S. (2010): Mobilization of potassium from waste mica by plant growth promoting rhizobacteria and its assimilation by maize (zea mays) and wheat (triticum aestivum): a hydroponics study under phytotron growth chamber. - J Plant Nutr 33: 1236-1251.

[33] Snyder, G. H. (2001): Calibration of soil and plant silicon analysis for rice production. - J Plant Nutr 24: 1071-1084.

[34] Soil Survey Staff. (2010): Keys to Soil Taxonomy. 11th Ed. - USDA Natural Resources Conservation Service, Washington, DC.

[35] Takahashi, E., Miyake, Y. (1976a): Distribution of silica accumulator plants in the plant kingdom (1) Monocotyledons. - J Sci Soil Manu Jpn 47: 296-300.

[36] Takahashi, E., Miyake, Y. (1976b): Distribution of silica accumulator plants in the plant kingdom (2) Dicotyledons. - J Sci Soil Manu Jpn 47: 301-306.

[37] Takahashi, E., Miyake, Y. (1976c): Distribution of silica accumulator plants in the plant kingdom (3) Gymnospermae, Pteridophyta, Bryophyta. - J Sci Soil Manu Jpn 47: 333337.

[38] Tamura, K., Dudley, J., Nei, M., Kumar, S. (2007): MEGA4: Molecular evolutionary genetics analysis (MEGA) software version 4.0. - Mol Biol Evol 24: 1596-1599.

[39] Thompson, J. D., Gibson, T. J., Plewniak, F., Jeanmougin, F., Higgins, D. G. (1997): The CLUSTAL_X windows interface: flexible strategies for multiple sequence alignment aided by quality analysis tools. - Nucleic Acids Res 25: 4876-4882.

[40] Uroz, S., Calvaruso, C., Turpault, M. P., Freyklett, P. (2009): Mineral weathering by bacteria: ecology, actors and mechanisms. - Trends Microbiol 17: 378-387.

[41] Vessey, J. K. (2003): Plant growth promoting rhizobacteria as biofertilizers. - Plant Soil 255: 571-586.

[42] Wang, Jim, J., Dodla, Syam, K., Henderson, Rodney, E. (2004): Soil silicon extractability with seven selected extractants in relation to colorimetric and ICP determination. - Soil Science 169: 861-870.

[43] Witzel, K., Strehmel, N., Baldermann, S., Neugart, S., Becker, Y., Becker, M., Berger, B., Scheel, D., Grosch, R., Schreiner, M., Ruppel, S. (2017): Arabidopsis thaliana root and root exudate metabolism is altered by the growth-promoting bacterium Kosakonia radicincitans DSM 16656(T). - Plant Soil 419: 557-573. 
[44] Wu, G. Q., Liu, H. L., Feng, R. J., Wang, C. M., Du, Y. Y. (2017): Silicon ameliorates the adverse effects of salt stress on sainfoin (Onobrychis viciaefolia) seedlings. - Plant Soil Environ 63: 545-551.

[45] Xiao, Y., Wang, X., Chen, W., Huang, Q. (2017): Isolation and identification of three potassium-solubilizing bacteria from rape rhizospheric soil and their effects on ryegrass. - Geomicrobiol J 34. DOI: 10.1080/01490451.01492017.01286416.

[46] Youssef, G. H., Seddik, W. M. A., Osman, M. A. (2010): Efficiency of natural minerals in presence of different nitrogen forms and potassium dissolving bacteria on peanut and sesame yields. - J Am Sci 6: 647-660.

[47] Zahra, M. K., Monib, M., Abdel-Al, S. I., Heggo, A. (1984): Significance of soil inoculation with silicate bacteria. - Zentralblatt für Mikrobiologie 139: 349-357.

[48] Zhang, C., Kong, F. (2014): Isolation and identification of potassium-solubilizing bacteria from tobacco rhizospheric soil and their effect on tobacco plants. - Appl Soil Ecol 82: 18-25. 